Western North American Naturalist 68(1), (C) 2008, pp. 76-82

\title{
DYNAMICS OF RODENT POPULATIONS IN SEMIARID HABITATS IN LASSEN COUNTY, CALIFORNIA
}

\author{
Sara C. Gillespie ${ }^{1,3}$, Dirk H. Van Vuren ${ }^{1}$, Douglas A. Kelt ${ }^{1,2}$, John M. Eadie ${ }^{1}$, and Daniel W. Anderson ${ }^{1}$
}

\begin{abstract}
From 1996 to 2004, we studied population dynamics of a rodent assemblage in semiarid habitats in Lassen County, California. Abundances of rodents appeared affected by fluctuations in precipitation from a high in 1996 to average and slightly below-average levels in subsequent years; perhaps reflecting this, assemblage composition also changed dramatically during the study period. California kangaroo rats (Dipodomys californicus) declined from abundant to extremely rare, abundances of deer mice (Peromyscus maniculatus) fluctuated greatly during the study period, and, perhaps most notably, populations of dusky-footed woodrats (Neotoma fuscipes) appeared to decline to local extinction, possibly allowing for the subsequent colonization of desert woodrats (N. lepida). These changes appeared to represent natural variation in numbers and composition in an ecologically dynamic ecotonal region in response to multiyear changes in precipitation.
\end{abstract}

Key words: small mammals, population dynamics, role of precipitation, Peromyscus maniculatus, Tamias, Dipodomys californicus, Neotoma fuscipes, Neotoma lepida.

Rodent assemblages are highly dynamic (Brown 1975, Brown and Zeng 1989, Heske et al. 1994, Shenbrot and Krasnov 2001, Lima et al. 2002), and changes in relative abundance as well as assemblage composition may be caused by complex interactions among a number of factors, including climate, plant production, food supply, vegetative cover, predation, and competition (e.g., Flowerdew 1987, Batzli 1992, Oli and Dobson 2001). A particularly well-studied factor influencing assemblages of small mammals is precipitation, especially in arid and semiarid habitats (Abramsky 1988, Owen 1988, Heske et al. 1994, Brown and Ernest 2002, Lima et al. 2002, Meserve et al. 2003, Letnic and Dickman 2005). Precipitation can have a direct positive influence on plant production, as measured by increased seed production and foliage growth (Heske et al. 1994, Lima et al. 2002). Additionally, precipitation can influence rodent populations indirectly via plant production and food supply, which affect rates of rodent reproduction, mortality, and dispersal (Shenbrot and Krasnov 2001, Letnic and Dickman 2005).

From 1996 through 2004, we studied assemblages of rodents in 3 habitats near Eagle Lake, northeastern California. Specifically, we predicted that in this arid region, assemblages of rodents would be strongly influenced by precipitation, which should influence both vegetative cover and food availability. Hence, we hypothesized that population size and body weight of rodents would be correlated positively with annual rainfall.

\section{Methods \\ Study Site}

We conducted our study near Eagle Lake Biological Field Station (ELBFS), $25 \mathrm{~km}$ NW Susanville, Lassen County, California, at an elevation of $1550 \mathrm{~m}$. ELBFS is located at the southeastern end of the Cascade Range in the rain shadow of the Cascade and Sierra Nevada ranges. Landscape around the field station is a mosaic of several habitats, most prominently shrubsteppe, juniper woodland, and montane coniferous forest.

We studied rodents in 3 habitats near ELBFS. Mixed conifer habitat was dominated by Jeffrey pine (Pinus jeffreyi), incense cedar (Calocedrus decurrens), and red fir (Abies magnifica), with approximately $50 \%$ canopy cover and a canopy height of 6-9 m. A sparse herbaceous layer was dominated by Mahala mat (Ceanothus prostratus), and the ground layer included rocks, stumps, and coarse woody debris. The juniper-woodland habitat was dominated

\footnotetext{
${ }^{1}$ Department of Wildlife, Fish, and Conservation Biology, University of California, Davis, CA 95616.

${ }^{2}$ Corresponding author. E-mail:dakelt@ucdavis.edu

${ }^{3}$ Present address: Robertson-Bryan, Inc., Elk Grove, CA 95624
} 


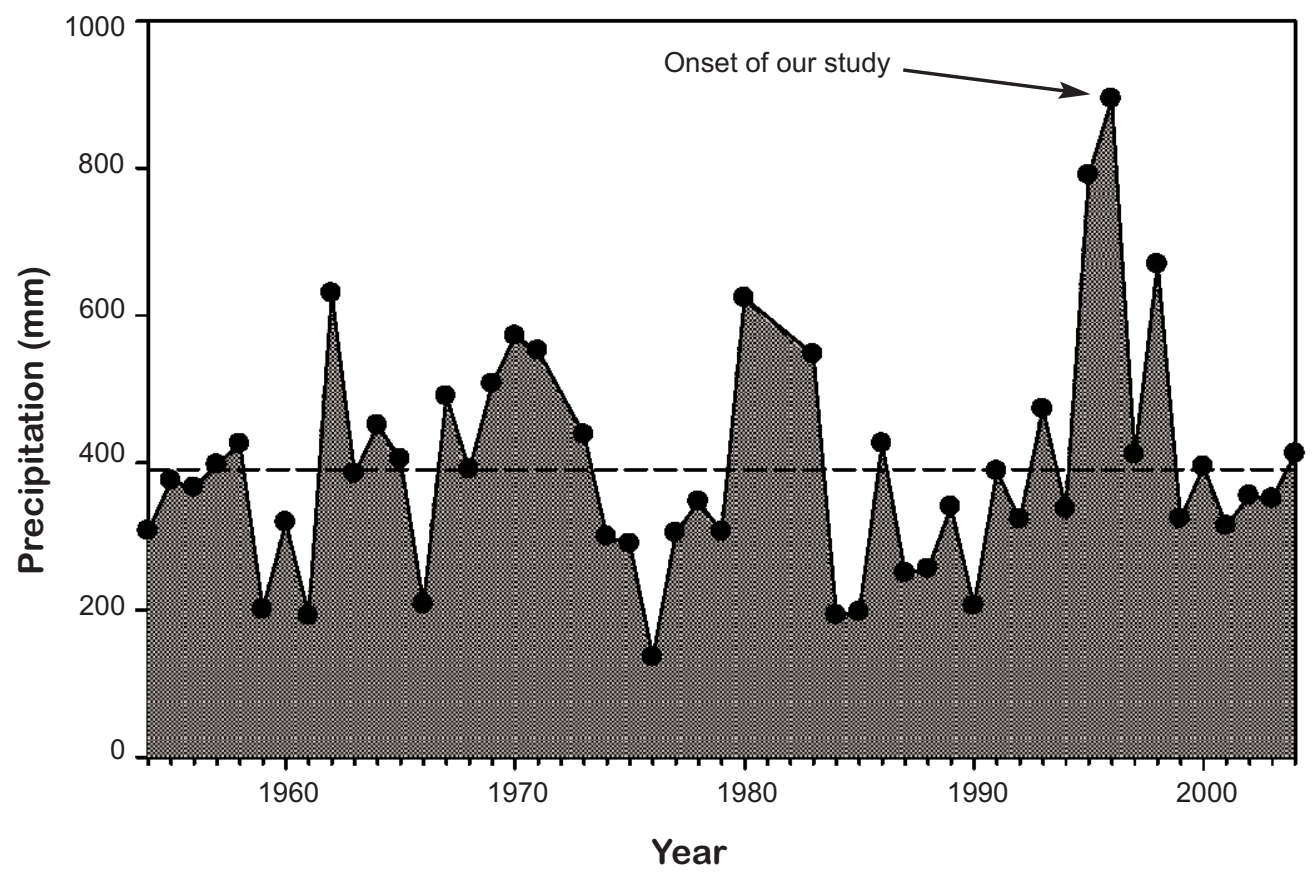

Fig. 1. Long-term precipitation records for Susanville, Lassen County, California (elevation $1550 \mathrm{~m}$ ), from 1954 to 2004. The long-term mean, $391 \mathrm{~mm}$, is indicated with the dashed line.

by western juniper (Juniperus communis), with scattered P. jeffreyi. Canopy cover was about $20 \%$ and canopy height was $2-10 \mathrm{~m}$. The understory was about $1 \mathrm{~m}$ in height, provided $60 \%$ ground cover, and was dominated by big sagebrush (Artemisia tridentata), rubber rabbitbrush (Chrysothamnus nauseosus), and mountain snowberry (Symphoricarpos vaccinioides). The ground layer was characterized by rocks and coarse woody debris interspersed with coarse rocky soil. The shrubsteppe habitat was dominated by $C$. nauseosus, which was $<1 \mathrm{~m}$ in height and provided about $30 \%$ cover, with a ground layer dominated by sparse annual grasses.

\section{Trapping Protocol}

We established a single trapping grid in each habitat. Grids were separated by about $0.5-1.5$ $\mathrm{km}$ and were comprised of 49 stations in a $7 \times$ 7 array with $10 \mathrm{~m}$ spacing (total area approximately $0.49 \mathrm{ha}$ ). At each station, we placed a single Sherman live trap (Model XLK) baited with rolled oats. Trapping was conducted for 3 consecutive nights each September from 1996 to 2004 for 147 trap nights at each grid in each year, except for 2001 and 2003 when we did not trap. The mixed conifer and shrubsteppe grids were not trapped in 1997, and in 2002, we trapped some grids for only 1-2 nights. Traps were opened at dusk, and we checked and closed them by 09:30 the following morning.

All rodents captured were identified to species, weighed, individually marked with numbered eartags (National Band and Tag Co., Newport, KY), and released. Because our trapping was conducted in late summer, virtually all captures were adults. Thus, we did not segregate analyses by age categories. A few voucher specimens of all species were deposited in the Museum of Wildlife and Fish Biology, University of California, Davis.

\section{Statistical Analyses}

Because our samples were snapshots of local composition separated by extended periods, we used the total number of unique individuals per trap night multiplied by 100 as a measure of the relative numbers of each species. Only species with captures in $\geq 1$ habitat for at least 4 of the 7 years of the study were included in analyses of individual species dynamics.

The closest weather station was at the California Department of Water Resources in 


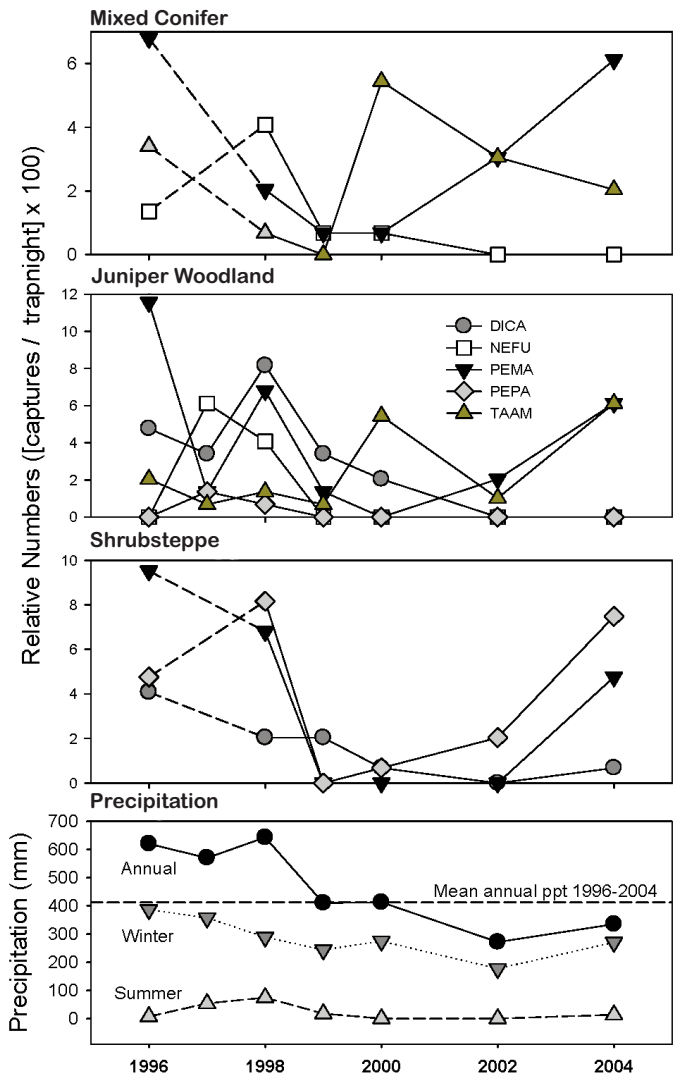

Fig. 2. Relative population sizes of rodents in 3 habitats near Eagle Lake Biological Field Station, Lassen County, California, including Dipodomys californicus (DICA), Neotoma fuscipes (NEFU), Peromyscus maniculatus (PEMA), Perognathus parvus (PEPA), and Tamias amoenus (TAAM). The lower panel presents winter, summer, and annual precipitation over the years of study. Mean annual precipitation for 1996-2004 was $412 \mathrm{~mm}$.

Susanville, California, $25 \mathrm{~km}$ from our sites and $270 \mathrm{~m}$ lower in elevation (data available from: http://cdec.water.ca.gov). Susanville is in the same climate zone as ELBFS (CDFG 2002 in CDFG 2003), so we assumed that patterns of precipitation were similar at both sites. We determined annual precipitation for each year beginning with 1954, and then calculated a long-term average for 1954-2004. Winter precipitation was calculated by summing totals for December, January, and February, and summer precipitation was calculated by summing totals for June, July, and August.

We used a correlation analysis to assess temporal variation between abundance of rodents and annual precipitation for each species in each habitat. Because data were not normally distributed, we converted values of abundance and precipitation to ranks before calculating Pearson's correlation coefficient. Because seasonal precipitation might be more important for some species than total annual precipitation (Lima et al. 2002), we also correlated abundances with winter and summer precipitation among years. We used a relaxed level of significance $(P<0.10)$ because of low statistical power, and we interpret results accordingly.

Finally, because reduced precipitation can affect body weight through reduced food production, we used $t$ tests to compare mean body weight per species per habitat in years of above-average rainfall and in years of belowaverage rainfall.

\section{RESUlts}

\section{Precipitation}

The long-term mean for annual precipitation (1954-2004) in Susanville was $391 \mathrm{~mm}$, with a range of $135 \mathrm{~mm}$ in 1976 to $894 \mathrm{~mm}$ in 1996. Precipitation reached its greatest level in the last 50 years near the onset of our study in 1996 and stayed above the long-term mean until 1998 (Fig. 1). Precipitation declined in 1999 and remained at or just below the longterm mean for the remainder of the study. During our study, mean precipitation for years of above-average rainfall (1996-1998) was 631 $\mathrm{mm}$, and mean precipitation for years of belowaverage rainfall (1999, 2000, 2002, and 2004) was $359 \mathrm{~mm}$.

\section{Rodent Abundance}

We captured 292 individuals of 10 species of rodents. Five species were sufficiently numerous to meet our criteria for individual species analysis, including the California kangaroo rat (Dipodomys californicus), dusky-footed woodrat (Neotoma fuscipes), Great Basin pocket mouse (Perognathus parvus), deer mouse (Peromyscus maniculatus), and yellow-pine chipmunk (Tamias amoenus; Fig. 2). The remaining 5 species were not found in sufficient numbers for further analysis; they included the western harvest mouse (Reithrodontomys megalotis), brush mouse (Peromyscus boylii), Piñon mouse (Peromyscus truei), golden-mantled ground squirrel (Spermophilus lateralis), and shadow chipmunk (= Allen's chipmunk, Tamias senex).

Species of small mammals varied greatly in their trajectories over time and across habitats 
TABLE 1. Results of correlation analyses between relative numbers of small mammals and 3 measures of precipitation near Eagle Lake Biological Field Station, Lassen County, California. Significant results $(P \leq 0.10)$ are in bold. DICA $=$ Dipodomys californicus, NEFU $=$ Neotoma fuscipes, PEMA = Peromyscus maniculatus, $\mathrm{PEPA}=$ Perognathus parvus, TAAM $=$ Tamias amoenus.

\begin{tabular}{lrrr}
\hline \multicolumn{4}{c}{ Annual pptn. Summer pptn. Winter pptn. } \\
\hline Mixed conifer & & & \\
NEFU & $\mathbf{0 . 7 6 7}$ & 0.274 & 0.449 \\
PEMA & -0.090 & -0.336 & 0.036 \\
TAAM & -0.072 & $\mathbf{- 0 . 8 1 8}$ & 0.072 \\
Juniper woodland & & & \\
DICA & $\mathbf{0 . 9 2 7}$ & 0.663 & 0.691 \\
NEFU & 0.579 & $\mathbf{0 . 7 6 4}$ & 0.490 \\
PEMA & $\mathbf{0 . 6 9 8}$ & 0.318 & 0.371 \\
PEPA & 0.579 & $\mathbf{0 . 7 6 4}$ & 0.490 \\
TAAM & -0.036 & -0.400 & 0.108 \\
Shrubsteppe & & & \\
DICA & $\mathbf{0 . 7 6 5}$ & 0.552 & $\mathbf{0 . 7 3 6}$ \\
PEMA & 0.638 & 0.400 & $\mathbf{0 . 8 2 0}$ \\
PEPA & 0.371 & 0.406 & 0.486 \\
\hline
\end{tabular}

(Fig. 2). In general, overall abundance declined during the early years of the study in juniper woodland and shrubsteppe habitats, then increased late in the study. This pattern was not evident in the mixed conifer forest. The decrease in abundance was especially apparent in D. californicus and N. fuscipes, which became locally extinct, or nearly so, at our sites in juniper woodlands (both species) and mixed conifer forests (only Neotoma). Some species declined and then recovered, such as $P$. parvus in the shrubsteppe habitat and $P$. maniculatus in all 3 habitats. Abundance of $T$. amoenus varied greatly from year to year, showing a peak in 2000 in both habitats in which it occurred.

Additionally, individual species differed in their responses to precipitation (Table 1). Abundances of 4 species correlated positively with at least 1 measure of precipitation. Neotoma fuscipes was correlated positively with annual precipitation in the mixed conifer forest and with summer precipitation in juniper woodlands. Dipodomys californicus was correlated positively with annual precipitation in the 2 habitats in which it occurred (juniper woodland and shrubsteppe) and with winter precipitation in shrubsteppe. Perognathus parvus was correlated positively with summer precipitation in juniper woodlands. Peromyscus maniculatus, the only species that occurred in all 3 habitats, demonstrated a consistently positive relationship with annual precipitation in jun- iper woodland and with summer precipitation in the shrubsteppe, but exhibited little evidence of any relationship in mixed conifer forest. In contrast, abundances of T. amoenus exhibited little or no relationship to precipitation, except for a significant negative correlation with summer precipitation in the mixed conifer forest. For this species, seasonal precipitation was no better than annual precipitation at explaining total abundance of rodents.

\section{Body Weight}

Only 1 species demonstrated a relationship between precipitation and body weight. Individuals of $P$. maniculatus were significantly lighter during periods of low precipitation in all 3 habitats (Table 2).

\section{Discussion}

Typical of arid regions, annual precipitation in eastern Lassen County has varied greatly during the past 50 years. A peak in annual precipitation in the late 1990s was followed by a decline to slightly below-average values. Rodents in this region did not respond linearly to the decline in precipitation. Of course, longterm patterns likely differ among species, and more complex responses by these species may exist that were not detected by our limited sampling regime.

Numerous studies report changes in densities of rodents following pulses in rainfall (e.g., Heske et al. 1994, Brown and Ernest 2002, Lima et al. 2002, Meserve et al. 2003, Kelt et al. 2005, Orland and Kelt 2007). At our site, correlation analyses did not reveal a strong relationship between overall abundance of rodents and precipitation. Most of the positive relationships observed were exhibited by $N$. fuscipes and D. californicus, the 2 species that experienced the most drastic declines. In contrast, correlations between T. amoenus and precipitation were either negative or about 0 , perhaps because this species forages extensively on seeds of woody plants that are not greatly affected by yearly variations in precipitation.

Plant production in semiarid habitats is linked closely to precipitation (e.g., Rosenzweig 1968, Brown and Ernest 2002, Meserve et al. 2003) and can influence rodent dynamics through reduced plant productivity during drought (Brown and Ernest 2002, Meserve et al. 2003). In the extreme, this could result in 
TABLE 2. Mean body weight (g) for predominant species in periods of above-average and below-average precipitation (pptn.) at Eagle Lake Biological Field Station, Lassen County, California. Significant results are in bold $(P \leq 0.10)$. DICA = Dipodomys californicus, $\mathrm{NEFU}=$ Neotoma fuscipes, PEMA $=$ Peromyscus maniculatus, $\mathrm{PEPA}=$ Perognathus parvus, TAAM = Tamias amoenus.

\begin{tabular}{|c|c|c|c|c|}
\hline & \multicolumn{2}{|c|}{ Mean body weight (g) } & \multirow[b]{2}{*}{$t$} & \multirow[b]{2}{*}{$P$} \\
\hline & Above-average pptn. & Below-average pptn. & & \\
\hline \multicolumn{5}{|c|}{ Mixed conifer grid } \\
\hline NEFU & $203.5(n=5)$ & $190.0(n=2)$ & 0.28 & 0.81 \\
\hline PEMA & $17.5(n=11)$ & $15.0(n=12)$ & 2.56 & 0.02 \\
\hline TAAM & $44.0(n=1)$ & $46.0(n=11)$ & 1.56 & 0.15 \\
\hline \multicolumn{5}{|c|}{ Juniper woodland grid } \\
\hline DICA & $80.0(n=27)$ & $81.4(n=16)$ & -0.41 & 0.68 \\
\hline NEFU & $170.1(n=13)$ & $177.0(n=1)$ & 0.19 & 0.85 \\
\hline PEMA & $18.2(n=21)$ & $14.8(n=11)$ & 3.42 & 0.01 \\
\hline TAAM & $49.1(n=2)$ & $45.6(n=12)$ & 2.43 & 0.14 \\
\hline \multicolumn{5}{|c|}{ Shrubsteppe grid } \\
\hline DICA & $79.7(n=8)$ & $85.3(n=9)$ & -1.29 & 0.22 \\
\hline PEPA & $20.2(n=11)$ & $19.5(n=9)$ & 0.36 & 0.72 \\
\hline PEMA & $20.6(n=14)$ & $15.4(n=9)$ & 3.74 & 0.00 \\
\hline
\end{tabular}

decreased body weights of rodents. Our analyses generally do not support this scenario, but we observed 1 exception. Most notably, $P$. maniculatus showed a significant increase in body weight in years with above-average precipitation in all 3 habitats. While these data are insufficient to invoke causality, they do make sense with respect to the ecology of this species. Peromyscus maniculatus is omnivorous and may respond positively to increased food in times of higher precipitation; both vegetation and insect biomass would be expected to be positively related to precipitation in arid environments.

Our evidence of a drastic decline in $N$. fuscipes is supported by concurrent studies of dusky-footed woodrats conducted over a much broader spatial scale; these studies also indicate potential replacement by the smaller desert woodrat (N. lepida). Trapping throughout 20 ha of juniper woodlands surrounding ELBFS revealed that $N$. fuscipes was abundant in 1998 and locally extinct by 2003 (McEachern et al. 2007, Veenstra personal communication). In $2002, N$. lepida was identified in traps set for $N$. fuscipes, although the former species generally was restricted to basalt bluffs located along the margin of juniper woodlands (M.B. McEachern, E. Gabbai-Saldate, and D.A. Kelt unpublished observations). Whether $N$. lepida was able to colonize this area because of reductions in numbers of dusky-footed woodrats or because of lower rainfall and subsequent changes in habitat structure and composition remains a topic for further research.
The geographic location of our site likely plays a role in understanding population and assemblage dynamics through time. Eagle Lake lies within the major ecological transition between coniferous forests of the northern Sierra Nevada and sagebrush habitat of the Great Basin. Consequently, several species found there are at or near the edge of their geographic range. If the abundance of species declines from the center of its range and becomes patchy at the edges of ranges (Brown 1984, Mehlman 1997, Doherty et al. 2003), then the lower density of populations at the edges probably are more likely to experience local extinctions and colonizations than larger central populations (Doherty et al. 2003).

Dipodomys californicus and N. fuscipes both reach the eastern (xeric) edge of their ranges at Eagle Lake (Ingles 1965, Kelt 1988, Jameson and Peeters 2004). In contrast, P. parvus and N. lepida are typical of the Great Basin and reach the western (mesic) edge of their ranges at Eagle Lake (Ingles 1965, Jameson and Peeters 2004). If the temporal turnover we observed was a reflection of shifting ecotonal characteristics, then we would expect the former species to increase at Eagle Lake during years of higher precipitation, and the latter to increase in years of lower precipitation. In spite of our limited sampling, our data supported this hypothesis.

For example, California kangaroo rats were present at our study sites in 1996, but declined in subsequent drier years. In contrast, however, the presence of $>300$ woodrat dens 
in the area around ELBFS in 1999 (McEachern unpublished data) suggests that $N$. fuscipes was not a recent colonist but a long-term inhabitant of the area. As noted above, however, the smaller $N$. lepida has been known from this region only in recent years when local populations of the larger $N$. fuscipes declined. Finally, $P$. parvus appeared to increase in abundance in response to increased precipitation in at least 1 habitat in the study area.

\section{Conclusions}

Populations and assemblages of small mammals are expected to be particularly dynamic within zones of major ecological transition. Eagle Lake is situated in 1 such transition, and, perhaps serendipitously, our sampling in 3 habitats in the area has provided some insights into temporal changes in assemblage structure. Observations to date allow us to make some specific predictions that could be assessed at this site or at other sites along this ecotone. First, local species richness at this ecotone was not highly influenced by interannual variation in precipitation. Variations in precipitation influenced composition of fauna, leading to a local turnover of species, but had little influence on the number of species present. Second, local population sizes of small mammals were significantly influenced by interannual variation in precipitation, such that total numbers were significantly higher during years of high precipitation.

Global climate change is predicted to influence the Sierra Nevada by increasing total precipitation by increasing rainfall at the expense of snowfall. This will lead to increased aridity during hot summer months because of reduced snowmelt. Thus, predictions for local responses of small mammals to potential climate change are somewhat ambiguous. Increased precipitation should favor more mesic taxa (e.g., N. fuscipes, D. californicus), whereas the reduced availability of moisture during hot summer months could favor xeric taxa (e.g., $N$. lepida, P. parvus). Other species of kangaroo rats (D. microps, $D$. ordii) occur within a few kilometers east of this site (Grinnell et al. 1930, Kelt personal observation), and distributions of these species could reach Eagle Lake given sufficient years of more xeric conditions. These changes could be amplified if longer periods of xeric or mesic conditions lead to turnover in plant species and in floristic structure and composition. Major ecotonal regions such as Eagle Lake are particularly suitable areas for long-term monitoring of plants and animals, especially given contemporary concerns of global warming.

\section{ACKNOWLEDGMENTS}

We thank the many groups of students who helped collect the data that this study was based on. Funding for student research at the ELBFS was generously provided by the Lloyd W. Swift Student Support Fund. Two anonymous reviewers and K. Geluso greatly improved the clarity of our presentation.

\section{Literature Cited}

ABRAMsky, Z. 1988. The role of habitat and productivity in structuring desert rodent communities. Oikos 52: 107-114.

Batzli, G.O. 1992. Dynamics of small mammal populations: a review. Pages 831-850 in D.R. McCullough and R.H. Barrett, editors, Wildlife 2001: populations. Elsevier Applied Science, London.

Brown, J.H. 1975. Geographical ecology of desert rodents. Pages 315-341 in M.L. Cody and J.M. Diamond, editors, Ecology and evolution of communities. Belknap Press, Cambridge, MA.

. 1984. On the relationship between abundance and distribution of species. American Naturalist 124:255-279.

Brown, J.H., And S.K.M. ERnEst. 2002. Rain and rodents: complex dynamics of desert consumers. BioScience 52:979-987.

Brown, J.H., And Z. ZEng. 1989. Comparative population ecology of eleven species of rodents in the Chihuahuan Desert. Ecology 70:1507-1525.

[CDFG] California Department of Fish and Game. 2002. California climate based on the Köppen Classification System. GIS coverage. Wildlife and Habitat Data Analysis Branch, Sacramento, CA.

2003. Atlas of the biodiversity of California. Sacramento, CA. 103 pp.

Doherty, P.F., T. Boulinier, AND J.D. NiCHOLs. 2003. Local extinction and turnover rates at the edge and interior of species' ranges. Annales Zoologici Fennici 40:145-153.

FLOWERDEW, J.R. 1987. Mammals: their reproductive biology and population ecology. Edward Arnold, London.

Grinnell, J., J. Dixon, And J.M. Linsdale. 1930. Vertebrate natural history of a section of northern California through the Lassen Peak region. University of California Press, Berkeley.

Heske, E.J., J.H. Brown, And S. Mistry. 1994. Longterm experimental study of a Chihuahuan Desert rodent community: 13 years of competition. Ecology 75:438-445.

IngLes, L.G. 1965. Mammals of the Pacific States: California, Oregon, and Washington. Stanford University Press, Stanford, CA. 
Jameson, E.W., Jr., and J.H. Peeters. 2004. California mammals. 2nd edition. University of California Press, Berkeley.

Kelt, D.A. 1988. Dipodomys californicus. Mammalian Species 324:1-4.

Kelt, D.A., J.A. Wilson, and E.S. Konno. 2005. Differential response of two kangaroo rat species (Dipodomys) to the 1997/98 El Niño Southern Oscillation event. Journal of Mammalogy 86:265-274.

Letnic, M., And C.R. Dickman. 2005. The responses of small mammals to patches regenerating after fire and rainfall in the Simpson Desert, central Australia. Austral Ecology 30:24-39.

Lima, M., N.C. Stenseth, And F.M. Jaksic. 2002. Population dynamics of a South American rodent: seasonal structure interacting with climate, density dependence and predator effects. Proceedings of the Royal Society of London 269:2579-2586.

McEachern, M.B., J.M. Eadie, and D.H. Van Vuren. 2007. Local genetic structure and relatedness in a solitary mammal, Neotoma fuscipes. Behavioral Ecology and Sociobiology 61:1459-1469.

MenLman, D.W. 1997. Change in avian abundance across the geographic range in response to environmental change. Ecological Applications 7:614-624.
Mesernve, P.L., D.A. Kelt, W.B. Milstead, and J.R. GutiérREZ. 2003. Thirteen years of shifting topdown and bottom-up control. BioScience 53:633646.

Oli, M.K., And F.S. Dobson. 2001. Population cycles in small mammals: the $\alpha$-hypothesis. Journal of Mammalogy 82:573-581.

ORLAND, M.C., AND D.A. Kelt. 2007. Responses of a heteromyid rodent community to large- and small-scale resource pulses: diversity, abundance, and homerange dynamics. Journal of Mammalogy 88:12801287.

OwEN, J.G. 1988. On productivity as a predictor of rodent and carnivore diversity. Ecology 69:1161-1165.

RosenzweIG, M.L. 1968. Net primary productivity of terrestrial communities: prediction from climatological data. American Naturalist 102:67-74.

Shenbrot, G., and B. Krasnov. 2001. Rodents in desert environment: is density dynamics really correlated with annual rainfall fluctuations? Pages 405-421 in I. Prakesh, editor, Ecology of desert environments. Scientific Publishers, Jodhpur, India.

Received 13 March 2007 Accepted 20 September 2007 